\title{
周術期の感染症 一ペインクリニックの感染症一
}

原賀勇壮 $^{* 1}$ 平田和彦*1 山浦 健 $^{* 2}$

[要旨] ペインクリニック領域の感染症についてまとめた．対象疾患は硬膜外カテーテル留置後あ るいは硬膜外ブロック後の硬膜外膿瘍, 脊髄くも膜下腔カテーテルポート留置後髄膜炎, 神経ブロ ック後の感染症とした. 各疾患の頻度と発生要因, 起因菌と感染メカ二ズム, 症状・診断・治療ご とに記載した. 機能的予後のみならず, 生命予後に直結する場合もあるので迅速な初期対応が必要 である. 具体的には神経学的診察, 画像検査, 培養検体採取, 感染症内科医および外科医との連携 までの一連の初期対応が必要である. ペインクリニック領域の臨床に携わる医師は, これらの病態 の知識は必須であると思われる.

キーワード: 硬膜外膿瘍, 髄膜炎, 神経ブロック, 感染症, ブドウ球菌

\section{はじめに}

ペインクリニック・神経ブロック領域の感染症と その原因菌, 症状, 診断, 治療についてまとめた. 日本ペインクリニック学会誌のデータベースより 「感染」のキーワードで検索できた 310 件の論文を 調査した。ペインクリニックでの処置後の合併症の 症例報告は 10 報告を見出した。 その内訳は硬膜外 膿瘍に関する 23 症例 8 報告，髄膜炎に関する 2 報告 であった。

\section{I 硬膜外膿瘍}

\section{1. 頻度と発生要因}

硬膜外カテーテル留置症例での硬膜外膿瘍は 0.04 〜 $0.052 \%$ の頻度である ${ }^{1)}$. 2 . 硬膜外腔にカテーテル を留置しない硬膜外ブロックの際はさらにまれであ

*1 福岡大学筑紫病院麻酔科

$* 2$ 福岡大学医学部麻酔科学
り国内のペインクリニック学会誌では 4 例が報告さ れている(表 1) $)^{3) \sim 6)}$.

硬膜外カテーテル留置に関連する発生要因として は，カテーテル留置期間の長さ，担癌患者や免疫抑 制患者，糖尿病，アルコール多飲，薬物投与などの 危険因子がある場合に硬膜外カテーテル感染の頻度 が増加する ${ }^{2), 7)}$ 。 カテーテル刺入部の管理は, 中心 静脈カテーテルの領域では消毒による感染予防効果 が知られている ${ }^{8) .9)}$ 。しかし, 消毒によりカテーテ ル等の感染が増えるとの報告もあり ${ }^{10), 11)}$ ，ぞのよう な刺入部の管理が感染対策上最も有効であるのか明 らかでない．消毒や患者の体の動きに伴うカテーテ ルー皮膚間の往復運動に注目し, カテーテルの往復 運動に伴い表層の菌が深層に侵入することが in vitro で証明されている ${ }^{12), 13)}$ 。今後, in vivoおよび臨床で の一層の研究の発展により, 新たな感染対策が生ま 


\begin{tabular}{|c|c|c|c|c|c|}
\hline & 渠 & $\begin{array}{l}\text { 洲 } \\
\text { 品 }\end{array}$ & 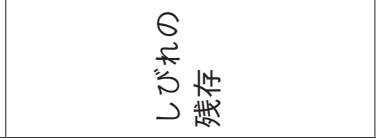 & 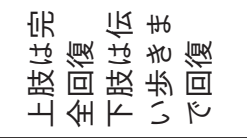 & 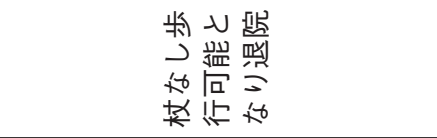 \\
\hline & 椤 & 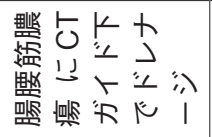 & 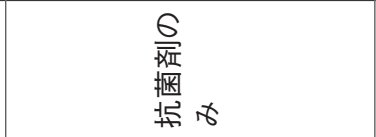 & 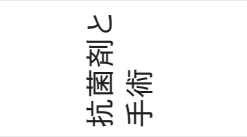 & 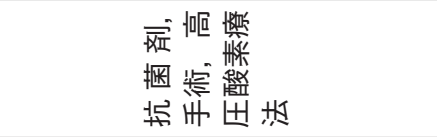 \\
\hline & $\begin{array}{l}\text { 示 } \\
\text { 㮯 } \\
\text { 望 }\end{array}$ & 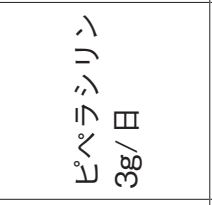 & 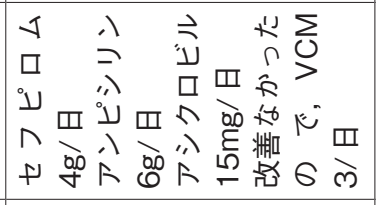 & 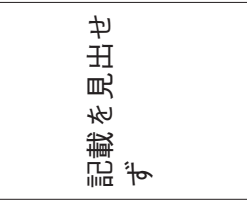 & 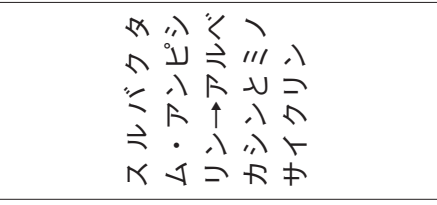 \\
\hline & 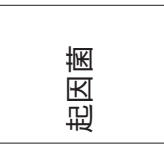 & 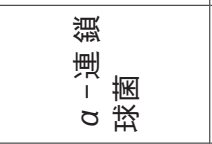 & 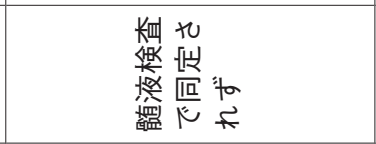 & 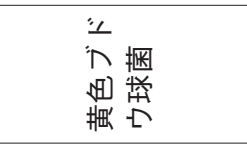 & 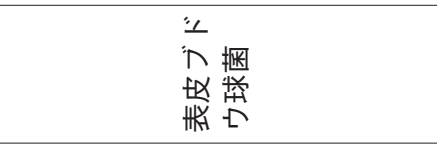 \\
\hline & 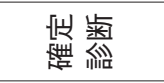 & $\overline{\underline{\Sigma}}$ & $\overline{\bar{x}}$ & $\overline{\underline{\Sigma}}$ & $\bar{\Sigma}$ \\
\hline & 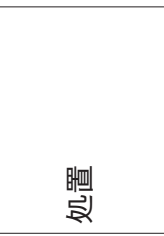 & 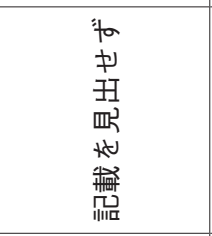 & 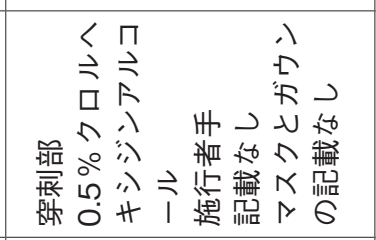 & 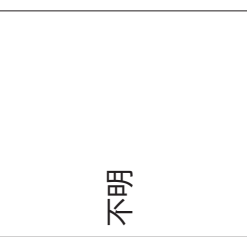 & 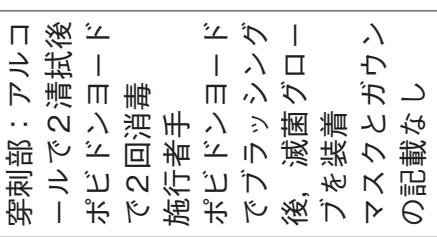 \\
\hline & $\begin{array}{l}\hat{N} \\
\approx\end{array}$ & 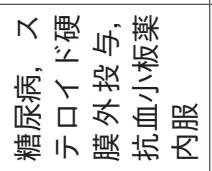 & $\underset{x \rightarrow 0}{\vec{x}}$ & 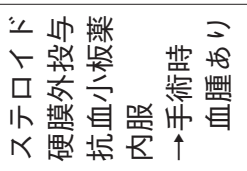 & $\underset{\langle\rightarrow \infty}{\vec{x}}$ \\
\hline & 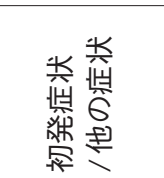 & 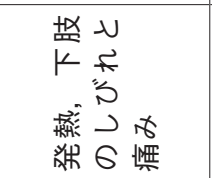 & 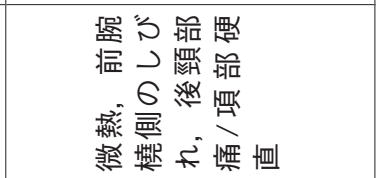 & 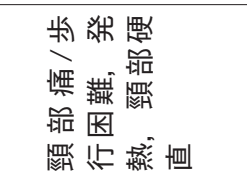 & 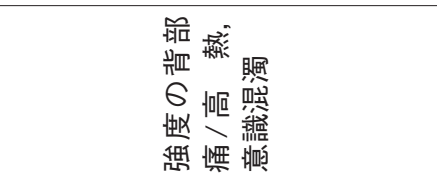 \\
\hline & 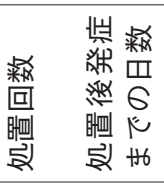 & 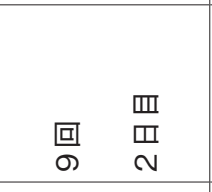 & 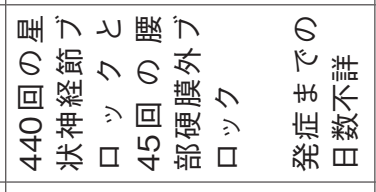 & 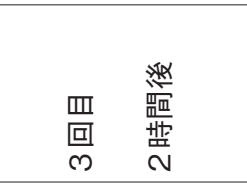 & $\begin{array}{ll}\text { 茴 } \\
\text { 茴 } \\
\text { 四 }\end{array}$ \\
\hline & 《棧 & $\mathscr{\infty}$ & $\mathscr{\varnothing}$ & 苟 & N \\
\hline & 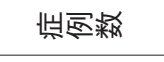 & - & - & - & - \\
\hline & 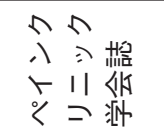 & 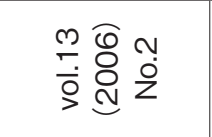 & 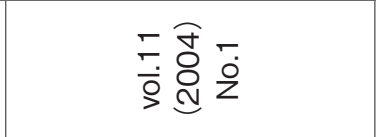 & 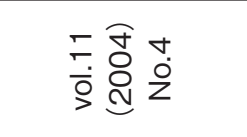 & 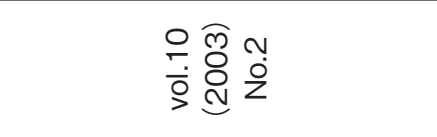 \\
\hline & $\begin{array}{l}\text { 盘 } \\
\text { 执 }\end{array}$ & 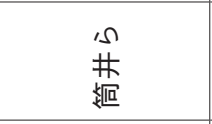 & $\begin{array}{l}\text { 品 } \\
\text { 思 }\end{array}$ & $\begin{array}{l}\text { 只 } \\
\text { 望 } \\
\text { 界 }\end{array}$ & 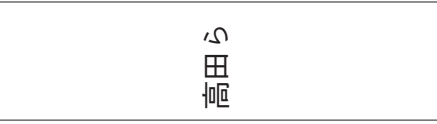 \\
\hline & $\begin{array}{l}\text { 焽 } \\
\text { 筮 }\end{array}$ & 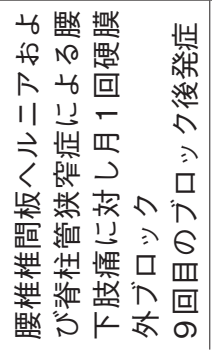 & 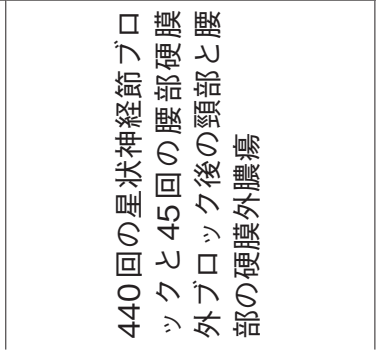 & 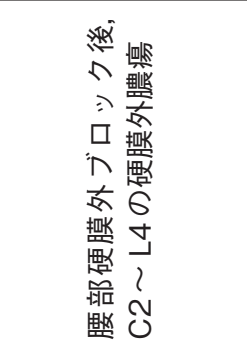 & 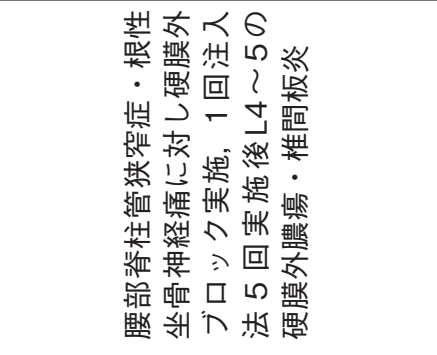 \\
\hline
\end{tabular}


れる可能性がある。

硬膜外ブロックの際の危険因子は, 硬膜外カテー テル留置の危険因子に加えて, 複数回の穿刺, ステ ロイド投与，抗血小板薬内服などが危険因子である 印象を受ける(表1)。しかし, 危険因子のない症例 でも発生しており不明な点が多い.

硬膜穿刺後髄膜炎の領域では, 医療者の鼻咽腔・ 口腔内常在菌や，不十分な針の滅菌・滅菌後の污染 が原因との報告があり ${ }^{14)}$, 硬膜外カテーテル留置や ブロックの際にもその危険性は同様であると思われ る。したがって, 穿刺部皮膚の消毒と医療者の手指 消毒・滅菌手袋の装着はもちろんのこと, 器具展開・ 薬剂準備の段階から周囲の人々のマスクの着用も徹 底されなければならない. 毛髪などの器具上への落 下による污染を防ぐために帽子と滅菌ガウンも使用 することが望ましい.

\section{2. 起因菌と感染メカニズム}

硬膜外膿瘍の最も多い起因菌はブドウ球菌であ る ${ }^{1)}{ }^{15)}$. 16). ブドウ球菌はバイオフィルム形成の能力 を持ち接着機能を備えている。この接着機能は異物 関連感染症におけるブドウ球菌の検出頻度が多いこ とに関連している ${ }^{17)}$. バイオフィルムを形成するこ とで, ブドウ球菌は生体内で食菌作用と抗菌剤への 耐性が増し生き残る能力が増すことになる ${ }^{18)}$. ブド ウ球菌はバイオフィルム形成能力だけでなく細胞壁 を肥厚させる能力でも抗菌剤への耐性を増す ${ }^{19)}$. こ れらの機序により黄色ブドウ球菌による異物関連感 染症の治療の困難を生じることが報告されてき $た^{17), 201,21)}$.

ブドウ球菌のバイオフィルムの産生能力は菌ごと に異なり，ブドウ球菌のバイオフィルムの産生能力 が高いほどカテーテルの往復運動 ${ }^{12), 13)}$ に伴う侵入速 度が速くなることが in vitroで示されている ${ }^{13)}$. 今 後, カテーテル感染症の危険性の高い菌のスクリー ニングやバイオフィルムのコントロールに注目した 感染対策への発展が期待される。

\section{3. 症状}

海外の報告によると，硬膜外膿瘍の最も頻度の高 い初発症状は脊柱の痛み $(89 \%)$, 麻痺(不全対麻痺, 対麻痺 [80\%]), 発熱・悪寒 $(67 \%)$, 根性痛 $(57 \%)$, 局所の圧痛 $(48 \%)$, 膀胱・直腸障害 $(37 \%)$, 異常感 覚 $(28 \%)$, 項部硬直 $(17 \%)$, 意識障害 $(7 \%)$ とさ れ ${ }^{22), 23)}$ ，国内での報告 ${ }^{3) \sim 7)}$ と矛盾しない.

\section{4. 診断}

確定診断は細菌の同定 ${ }^{22)}$ に基づくが，同定までに 時間を要し，同定できないこともある，MRIが硬 膜外膿瘍の最適な画像検査であり ${ }^{22)}$ ，国内の報告で も頻用されている ${ }^{3) \sim 6)}$. T2 強調像で特徵的な高輝 度変化を示す ${ }^{22)}$. しかし, 脊髄液も T2 強調像で高 輝度変化を示すので，わずかな膿瘍では偽陰性にな る可能性がある ${ }^{22)}$. ガドリニウムの投与で硬膜外腔 の膿は強調されるが春髄液は $\mathrm{T} 1$ 強調で低輝度を示 し, 硬膜外膿瘍の検出感度は増加する ${ }^{22)}$ 。硬膜外静 脈叢はガドリニウムの投与で増強され，硬膜外膿瘍 と鑑別が困難なことがある ${ }^{222}$.

\section{5. 治療}

神経学的異常が軽微な症例では内科的治療のみで も予後は良好とされる。しかし，治療開始直前の神 経学的異常が重篤なほど，予後は不良である。保存 的治療を選択した場合には，神経学的評価や MRI による評価を注意深く行い，神経学的異常の変化や 病変が拡大した場合には，迅速な手術治療を考慮す べきである ${ }^{7)}$. 24)．36 時間未満の不全麻痺の患者の大 部分は完全に回復するが，36〜 48時間の完全麻痺 の患者では神経学的機能の回復は難しい ${ }^{222}$.

外科的治療の検討と並行して，抗菌治療を開始す べきである。しかし，抗菌治療に先立ち，膿瘍・血 液・脊髄液などの検体を採取しグラム染色を行い, その結果を使用する抗菌剤の選択に反映させるべき である ${ }^{22)}$ 。できるだけ早期の感染症専門医へのコン サルテーションが望ましい。早期のコンサルテーシ ヨンが困難な場合は髄膜炎との鑑別困難・䯣膜炎へ の進行予防に対応する意味でも髄膜炎治療と同様に 
行う。すなわち, 16 歳未満まではカルバペネム系 抗菌剂と第 3 世代セフェム系抗菌剂を併用 ${ }^{25)}$, 50歳 未満ではカルバペネム系抗菌剤のみ ${ }^{25}$ ，50歳以上 ではカルバペネムまたは第 3 世代セフェム系抗菌剤 としアンピシリンまたはバンコマイシンを追加す る ${ }^{25)}$. メチシリン耐性黄色ブドウ球菌(MRSA)の検 出率の高い施設では早期にバンコマイシンあるいは リネゾリドの併用を検討する ${ }^{25), 26)}$.

\section{II 脊髄くも膜下腔カテーテルポート留置後髄膜炎}

\section{1. 頻度}

脊髄くも膜下腔カテーテルポート留置による春髄 くも膜下鎮痛法に際して, カテーテル感染に至った 症例が報告されている ${ }^{27)}$, 28) . 脊髄くも膜下鎮痛法の カテーテル感染の発生率は $2.9 \%$ である ${ }^{29)}$.

\section{2. 起因菌と感染メカニズム}

本邦では，メチシリン感受性黄色ブドウ球菌が検 出された 1 報告 ${ }^{27)}$ と菌が検出されなかった 1 報告が ある ${ }^{28)}$. カテーテルポートのない硬膜穿刺後髄膜炎 の場合には, 口腔内常在菌のビリダンス連鎖球菌が $49 \%$ と多く, 他は黄色ブドウ球菌, 緑膿菌, エンテ ロコッカスフェカリス等であり，36\%では起炎菌は 明らかでない ${ }^{14)}$.

\section{3. 症状}

髄膜炎の発症の前に, 腰部カテーテル穿刺部に浮 腫と表皮剥離，髄液漏出などのポート部の污染状況 がある ${ }^{27), 28)}$.

髄膜炎の症状として，頭痛，頸部痛，発熱，嘔吐， 羞明, 高血圧, 感覚障害, 意識障害, 痤攣, 失見当 識，呼吸・循環障害，水頭症，脳浮腫，中枢性尿崩 症などの症状をきたす ${ }^{14)}$.

\section{4. 診断}

ポート部の污染の存在を背景に上述の症状の出現 により髄膜炎の発症を疑い, 細菌性髄膜炎診療ガイ ドライン ${ }^{25)}$ を参考に緊急の対応が必要である。血液 検査・血液培養検体 2 セット採取と神経所見診察, 頭部 CT 検査と画像確認までを 1 時間以内に行うこ
とを目標とする。髄液検査・髄液培養検体採取のた めの腰椎穿刺が必要だが，先の検査(血液，CT)で 腰椎穿刺の禁忌病態(頭蓋内圧光進，出血傾向)を除 外する。

\section{5. 治療}

培養検査検体採取後，広域スペクトル抗菌剂と補 助的治療をすぐに行う。使用する抗菌剂は硬膜外膿 瘍の治療の欄を参照されたい。カテーテルポートの ない通常の髄膜炎の場合には副腎皮質ステロイド薬 (デキサメタゾン)を抗菌剤の投与直前に併用するこ とで予後を改善する ${ }^{14), 25)}$ とされるが，カテーテルポ ートのある場合の予後は明らかでない.

\section{III＼cjkstart神経ブロック領域の感染症}

\section{1. 頻度と発生要因}

神経ブロックは実施部位とカテーテルの留置期間 により感染症の頻度は異なる。感染の危険性の高い のは，腕神経叢ブロック(腋窩アプローチ) と大腿神 経ブロックであり ${ }^{30)}$ ，いずれもカテーテルの留置4 日目には局所での炎症が $10 \%$ 前後発症する ${ }^{30)}$ 。神 経ブロック領域感染の発生に影響を与える要因とし ては，留置期間の長さ，抗菌剤の使用がないこと， 集中治療室患者(外傷患者)などがあげられる ${ }^{30}$.

\section{2. 起因菌と感染メカニズム}

カテーテル刺入部周囲皮膚やカテーテル污染から 最も検出される菌は表皮ブドウ球菌である。しかし， カテーテル感染症や膿瘍から最も検出される菌は黄 色ブドウ球菌である ${ }^{30)}$. 表皮ブドウ球菌と黄色ブド ウ球菌で検出される病態が異なる原因は明らかでな い.

\section{3. 症状, 診断, 治療}

カテーテル刺入部近傍の炎症所見を見極め，カテ ーテル抜去，培養検体提出を行う必要がある。カテ ーテル刺入部位近傍の CT または MRIにより，周辺 組織への炎症の波及・ガス像の有無など重篤な影響 の有無を見極女る。炎症の波及により気道狭窄 ${ }^{311} や$ 敗血症をきたしている場合の治療はカテーテル抜 
去・培養検体採取後, 硬膜外膿瘍の欄で紹介した抗 菌剤の使用法に順じて行う。保存的な治療だけでな く, 気管切開 ${ }^{31)}$, 壊死組織除去 ${ }^{32)}$ など外科的処置の 選択も考慮する.

\section{参考文献}

1) Wang LP, Hauerber J, Schmidt JF : Incidence of spinal epidural abscess after epidural analgesia : a national 1-year survey. Anesthesiology $91:$ 1928-1936, 1999

2) Ruppen W, Derry S, McQuay HJ, et al. : Infection rates associated with epidural indwelling catheters for seven days or longer : systematic review and metaanalysis. BMC Palliat Care 6:3, 2007

3）筒井雅人, 唐澤富士夫, 児玉光厳ほか：硬膜外ブロッ ク療法中に硬膜外膿瘍と腸腰筋膿瘍を発症した 1 症例. 日本ペインクリニック学会誌 $13 ： 132-135,2006$

4）池田東美明, 鈴木尚志, 野本功一ほか：神経ブロック 療法中に硬膜外膿瘍・椎間板炎を発症した症例。日本 ペインクリニック学会誌 $11 ： 12-15,2004$

5）田澤史恵, 塚越裕, 中村京一ほか：硬膜外ブロック後, 広範囲硬膜外膿瘍をきたした 1 症例。 日本ペインクリニ ック学会誌 $11: 457-459,2004$

6) 高田正史, 福崎誠, 寺尾嘉彰ほか：1回注入法での硬膜 外ブロック治療経過中に硬膜外膿瘍および椎間板炎を 発症した 1 例. 日本ペインクリニック学会誌 $10 ： 161-$ 164, 2003

7）泉薰, 松山博之: 脊䯣硬膜外膿瘍：16症例の解析. 日 本ペインクリニック学会誌 19：19-24, 2012

8) Yamamoto $\mathrm{N}$, Kimura H, Misao H, et al. : Efficacy of $1.0 \%$ chlorhexidine-gluconate ethanol compared with $10 \%$ povidone-iodine for long-term central venous catheter care in hematology departments : a prospective study. Am J Infect Control 42:574-576, 2014

9) Vallés J, Fernández I, Alcaraz D, et al. : Prospective randomized trial of 3 antiseptic solutions for prevention of catheter colonization in an intensive care unit for adult patients. Infect Control Hosp Epidemiol 29 : 847-853, 2008

10) Morin AM, Kerwat KM, Klotz M, et al. : Risk factors for bacterial catheter colonization in regional anaesthesia. BMC Anesthesiol $5: 1,2005$

11) Kao HK, Chen MC, Lee WC, et al. : A prospective comparative study of pin site infection in pediatric supracondylar humeral fractures : daily pin care vs. no pin care. Arch Orthop Trauma Surg 134 : 919-923, 2014

12) Haraga I, Higa K, Abe S, et al. : A novel model of epi- dural catheter-related infection : the importance of repeated catheter movements. JJSPC $23: 1-7,2016$

13) Haraga I, Abe S, Jimi S, et al. : Increased biofilm formation ability and accelerated transport of Staphylococcus aureus along a catheter during reciprocal movements. J Microbiol Methods $132: 63-68,2017$

14) Baer ET : Post-dural puncture bacterial meningitis. Anesthesiology $105: 381-393,2006$

15) Mishra S, Bhatnagar S, Srikanti M, et al. : Clinical implication of routine bacterial culture from epidural catheter tips in postoperative cancer patients : a prospective study. Anaesthesia $61: 878-882,2006$

16) Zimmerer SM, Conen A, Müller AA, et al. : Spinal epidural abscess : aetiology, predisponent factors and clinical outcomes in a 4-year prospective study. Eur Spine J 20 : 2228-2234, 2011

17) Foster TJ, Geoghegan JA, Ganesh VK, et al. : Adhesion, invasion and evasion : the many functions of the surface proteins of Staphylococcus aureus. Nat Rev Microbiol $12:$ 49-62, 2014

18) Otto A, van Dijl JM, Hecker M, et al. : The Staphylococcus aureus proteome. Int J Med Microbiol 304 : 110-120, 2014

19) Cui L, Ma X, Sato K, et al. : Cell wall thickening is a common feature of vancomycin resistance in Staphylococcus aureus. J Clin Microbiol $41: 5-14,2003$

20) Cassat JE, Smeltzer MS, Lee CY : Investigation of biofilm formation in clinical isolates of Staphylococcus aureus. Methods Mol Biol 1085 : 195-211, 2014

21) Koch G, Yepes A, Förstner KU, et al. : Evolution of resistance to a last-resort antibiotic in Staphylococcus aureus via bacterial competition. Cell 158 : 1060-1071, 2014

22）井上真輔, 川崎元敬訳 : Infections of the spine, Rothman-Simeone The Spine 脊椎・脊䯣外科(原著5版). 小宮節郎総監訳. 金芳堂, 京都, 2009, 1265-1316

23) Tang HJ, Lin HJ, Liu YC, et al. : Spinal epidural abscess--experience with 46 patients and evaluation of prognostic factors. J Infect $45: 76-81,2002$

24) Aboul-Enein HA, Fouad WA, Yehia A, et al. : Acute spinal epidural abscess : clinical presentations and surgical management. Bull Alex Fac Med $44: 431-436$, 2008

25）「細菌性䯙膜炎診療ガイドライン」作成委員会編：細菌 性髄膜炎診療ガイドライン 2014. 南江堂, 東京, 2015 (http://www.neuroinfection.jp/pdf/guideline101.pdf)

26） MRSA 感染症の治療ガイドラインー2014年改訂版. 日 本化学療法学会雑誌 $62: 533-604,2014$

27）原田紳介, 太田周平, 小川賢一ほか：脊髄くも膜下䏶 
カテーテルポートを留置後に髄液漏からカテーテル感 染を生じた 1 例. 日本ペインクリニック学会誌 19 : 508-511, 2012

28）前田倫, 菅島裕美, 松村陽子ほか：〈も膜下鎮痛(皮下 ポート)法に合併した髄膜炎をポート非抜去にて治療し た難治性がん性痛の 1 症例. 日本ペインクリニック学会 誌 $21: 519-523,2014$

29) Aprili D, Bandschapp O, Rochlitz C, et al. : Serious complications associated with external intrathecal catheters used in cancer pain patients : a systematic review and meta-analysis. Anesthesiology 111 : 1346-
1355,2009

30) Capdevila X, Bringuier S, Borgeat A : Infectious risk of continuous peripheral nerve blocks. Anesthesiology 110 : 182-188, 2009

31) Hasegawa J, Hidaka $H$, Tateda M, et al. : An analysis of clinical risk factors of deep neck infection. Auris Nasus Larynx 38 : 101-107, 2011

32) Dott D, Canlas C, Sobey C, et al. : Necrotizing fasciitis as a complication of a continuous sciatic nerve catheter using the lateral popliteal approach. Reg Anesth Pain Med 41 : 728-730, 2016 